\title{
COMPARATIVE STUDY OF THE IN-HOSPITAL CASE-FATALITY RATE OF LEPTOSPIROSIS BETWEEN PEDIATRIC AND ADULT PATIENTS OF DIFFERENT AGE GROUPS
}

\author{
Antonio Alberto LOPES(1,2), Everaldo COSTA(3,4), Yara Aragão COSTA(4), Edilson SACRAMENTO(3,4), Antonio Ralph Ribeiro de OLIVEIRA JUNIOR(1), \\ Marcelo Barreto LOPES(1) \& Gildete Barreto LOPES(2)
}

\begin{abstract}
SUMMARY
The main objective was to compare the in-hospital case-fatality rate of leptospirosis between pediatric $(<19$ years $)$ and adult $(\geq$ 19 years) patients, taking into account gender, renal function, duration of symptoms and jaundice. Medical records of 1016 patients were reviewed. Comparative analysis was restricted to 840 patients (100 pediatric, 740 adults) with recorded information on the variables included in the analysis. Among these patients $81.7 \%$ were male and $91.5 \%$ were icteric. The case-fatality rate of leptospirosis was $14.4 \%$. The odds of death adjusted for gender, jaundice, duration of symptoms, serum urea and serum creatinine were almost four times higher for the adult than for the pediatric group (odds ratio $(O R)=3.94 ; 95 \%$ confidence interval $=1.19-13.03, p=0.029$ ) . Among adults, increased age was also significantly and independently associated with increased risk of death $(\mathrm{p}<0.01)$. Older patients were also more often treated by dialysis. In conclusion, the data suggest that the in-hospital case fatality rate of leptospirosis is higher for adults than for children and adolescents, even after taking into account the effects of several potential risk factors of death. Among adults, older age was also strongly and independently associated with higher risk of death.
\end{abstract}

KEYWORDS: Leptospirosis; Group; Case-Fatality Rate; Mortality

\section{INTRODUCTION}

In Salvador, capital of Bahia and several other urban cities in Brazil, leptospirosis is endemic with outbreaks occurring in close relation to raining periods and floods ${ }^{2,4,11,14,15}$. Among the hospitalized cases, there is a predominance of males and patients with ages between 19 and 39 years. The risk of death in these patients with leptospirosis admitted to hospitals in Salvador has ranged from $12 \%$ to $15 \% \%^{2,10,19}$, being higher for jaundiced patients and those with renal failure. It has been argued that the high in-hospital death risk of patients with leptospirosis is partially due to the delay to initiate antibiotic therapy ${ }^{7,10}$. This delay to start the treatment of leptospirosis may be related to the fact that patients with leptospirosis, both children and adults, are often misdiagnosed as having other infectious diseases, particularly viral diseases ${ }^{7,17}$.

The existing data also suggest that the case-fatality rate of leptospirosis is lower in children and adolescents than in adults and higher in the elderly than in younger adults ${ }^{3,18}$. There is a lack of studies, however, developed specifically to compare the prognosis of leptospirosis between patients of different age groups. We studied a large sample of patients of different age groups with the diagnosis of leptospirosis who were admitted to a reference infectious disease hospital (Couto Maia Hospital), located in the city of Salvador. The main objective was to compare mortality risk between pediatric ( $<19$ years) and adult ( $\geq 19$ years) patients of different age groups, taking into account renal function, duration of symptoms and the presence of jaundice at hospital admission. We also compared age groups regarding treatment by dialysis and length of hospitalization.

\section{METHODS}

A retrospective study of 1016 patients diagnosed as leptospirosis who were admitted to Couto Maia Hospital, Salvador, BA, Brazil, between 1993 and 1997. Data were abstracted from medical charts, after obtaining approval by the institutional review committee. The comparative analysis was restricted to patients with recorded information on death, age, duration of symptoms and initial levels of serum creatinine and urea. The diagnosis of leptospirosis was based on clinical, laboratory and epidemiological data according to the World Health Organization (WHO) criteria $^{6}$. All patients reached at least 26 points according to the WHO criteria, a limit to define a case as having a high probability of leptospirosis ${ }^{6}$.

The patients were divided into pediatric ( $<19$ years) and adult groups ( $\geq 19$ years). Patients from the adult group were further classified according to the following age categories: 19-29, 30-39, 40-49, 50-59 and $\geq 60$ years.

(1) Departamento de Medicina da Faculdade de Medicina da Universidade Federal da Bahia (UFBA), Salvador, BA; Diretoria Científica do Hospital San Rafael, Salvador, BA, Brasil

(2) Núcleo de Epidemiologia Clínica do Hospital Universitário Professor Edgard Santos, UFBA, Salvador, BA, Brasil.

(3) Hospital Couto Maia da Secretaria de Saúde do Estado da Bahia, Salvador, BA, Brasil.

(4) Departamento de Medicina da Escola Bahiana de Medicina e Saúde Pública, Salvador, BA, Brasil.

Correspondence to: Dr. Antonio Alberto Lopes, R. Marechal Floriano 448, apto. 1301, Canela, 40110-010 Salvador, BA, Brasil. E-mail: aaslopes@ufba.br 


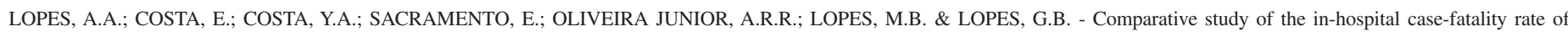
leptospirosis between pediatric and adult patients of different age groups. Rev. Inst. Med. trop. S. Paulo, 46(1):19-24, 2004.

The t-test for independent samples and one-way analysis of variance were used to compare quantitative variables. The chi-square test, or the Fisher's exact test, was used to compare proportions. A non-parametric test was used to compare medians ${ }^{13}$. This median test compares the groups regarding the number of cases with values greater than the observed median and less than or equal to the median. Multivariate logistic regression was used to estimate the association between age and mortality risk, adjusted for gender, duration of symptoms ( $>4$ days versus $\leq 4$ days), presence of jaundice, and initial levels of serum creatinine and serum urea. The statistical tests were two-tailed and $\mathrm{p}$ values below 0.05 were considered statistically significant.

\section{RESULTS}

Among 1016 cases, 840 (100 pediatric and 740 adult patients) had complete information on the variables of main interest. Among the pediatric patients, 34 were fourteen years old or younger and 66 were between 15 and 18 years of age. Males corresponded to $81.7 \%$ of these 840 subjects and $91.5 \%$ were considered icteric at hospital admission. An abrupt start of the clinical manifestations characterized by a combination of fever, myalgia and headache was described for $98.6 \%$ of the patients (828/840). The median duration of symptoms at admission was six days. Among the 176 patients excluded from the analysis because of missing values $97.2 \%$ were icteric and $78.4 \%$ were male.

Table 1 shows the patient characteristics at hospital admission by age groups. The percent of males was significantly higher among pediatric $(93 \%)$ than among adult $(80.1 \%)$ patients $(\mathrm{p}=0.002)$. Among adults, the percentage of males also decreased markedly as age increased, varying from $88.7 \%$ for ages $19-29$ years to $51.5 \%$ for ages $\geq 60$ years. The mean age was $34.1 \pm 14.4$ years for males and $44.7 \pm 16.2$ years for females $(\mathrm{p}<0.001)$. A significant lower percentage of jaundice was observed among pediatric ( $80.0 \%$ vs $93.1 \%$ in adults) patients; however, significant variation in the percentage of jaundiced patients was not observed across the adult age groups. Duration of symptoms did not vary significantly by age. In general, more than $75 \%$ of the patients had more than four days of symptoms at hospital admission. Both serum creatinine and urea levels increased significantly with age. More than $90 \%$ of the patients of the several age groups had serum creatinine $>1.2 \mathrm{mg} / \mathrm{dl}$ at hospital admission. By using different cut points for serum creatinine, differences by age became statistically significant $(\mathrm{p}<0.05)$ for levels $>3.0 \mathrm{mg} / \mathrm{dl}$. Similar percentages $(\mathrm{p}=0.603)$ of patients with serum creatinine $>1.0 \mathrm{mg} / \mathrm{dl}$ were observed for ages $\leq 14(94.1 \%)$ and ages $15-18$ years $(97.0 \%)$. The levels of bilirrubins, aspartate aminotransferase and alanine aminotransferase did not vary significantly by age. We have not observed a significant difference in the use of penicillin during hospitalization between the pediatric $(82 \%)$ and the adult $(78 \%)$ patients. Among adults, however, there was a significant, non-linear, variation in the percentage of patients who received penicillin by age groups with lower percentages being observed for ages 50 to 59 years $(65 \%)$. The percentage of patients who received penicillin therapy during the hospitalization period was significantly higher $(\mathrm{p}<0.001)$ in patients with duration of symptoms $\leq 4$ days $(90.2 \%$ versus $75 \%)$. The variation in penicillin use across the adult age groups remained significant after logistic regression adjustment for duration of symptoms.

In the total sample of 1016 cases, information on death or survival was missing for seven patients transferred to other hospitals (four in the age group $\geq 60$ years, one in the group 30-39, one in the group 40-49 and one in the group 50-59 years). The case-fatality rate was $14.2 \%$ for

Table 1

Baseline characteristics and penicillin use during hospitalization by age groups

\begin{tabular}{|c|c|c|c|c|c|c|c|c|c|}
\hline & \multirow{2}{*}{$\begin{array}{c}\text { Pediatric } \\
\quad<19 \\
n=100\end{array}$} & \multicolumn{5}{|c|}{ Adult age groups } & \multirow{2}{*}{$\begin{array}{l}\text { All Adults } \\
\begin{array}{c}\geq 19 \\
\mathrm{n}=740\end{array}\end{array}$} & \multirow[b]{2}{*}{$\begin{array}{l}\mathrm{p} \text { among } \\
\text { adults }\end{array}$} & \multirow[b]{2}{*}{$\begin{array}{l}\mathrm{p} \text { (pediatric } \\
\text { vs adults) }\end{array}$} \\
\hline & & $\begin{array}{c}19-29 \\
n=213\end{array}$ & $\begin{array}{c}30-39 \\
n=214\end{array}$ & $\begin{array}{c}40-49 \\
n=145\end{array}$ & $\begin{array}{c}50-59 \\
n=100\end{array}$ & $\begin{array}{c}\geq 60 \\
\mathrm{n}=68\end{array}$ & & & \\
\hline$\%$ male & 93.0 & 88.7 & 86.9 & 78.6 & 69.0 & 51.5 & 80.1 & $<0.001$ & 0.002 \\
\hline$\%$ jaundiced & 80.0 & 90.1 & 94.4 & 94.5 & 94.0 & 94.1 & 93.1 & 0.388 & $<0.001$ \\
\hline$\%$ symptoms $>4$ days & 75.0 & 73.7 & 74.8 & 74.5 & 83.0 & 77.9 & 75.8 & 0.439 & 0.859 \\
\hline Creatinine (mg/dl) & $3.3 \pm 1.7$ & $3.8 \pm 2.3$ & $4.1 \pm 2.4$ & $4.7 \pm 2.7$ & $4.4 \pm 2.2$ & $4.9 \pm 2.5$ & $4.2 \pm 2.5$ & 0.001 & $<0.001$ \\
\hline$\%$ creatinine $>0.8$ & 97.0 & 99.1 & 98.1 & 100.0 & 99.0 & 98.5 & 98.7 & $0.520 *$ & $0.133^{*}$ \\
\hline$\%$ creatinine $>1.0$ & 96.0 & 94.8 & 96.3 & 98.6 & 97.0 & 97.1 & 96.5 & 0.429 & $0.773 *$ \\
\hline$\%$ creatinine $>1.2$ & 91.0 & 91.5 & 92.5 & 94.5 & 96.0 & 94.1 & 93.2 & 0.594 & 0.410 \\
\hline$\%$ creatinine $>1.4$ & 89.6 & 88.2 & 90.1 & 92.2 & 93.0 & 91.0 & 90.4 & 0.628 & 0.793 \\
\hline$\%$ creatinine $>2.5$ & 60.0 & 64.3 & 66.4 & 74.5 & 75.0 & 76.5 & 69.5 & 0.079 & 0.056 \\
\hline$\%$ creatinine $>3.0$ & 45.0 & 55.4 & 59.8 & 65.5 & 69.0 & 75.0 & 62.3 & 0.017 & 0.001 \\
\hline Urea $(\mathrm{mg} / \mathrm{dl})$ & $121.8 \pm 80.3$ & $128.2 \pm 85.6$ & $144.7 \pm 90.3$ & $159.1 \pm 98.0$ & $196.7 \pm 119.7$ & $201.6 \pm 115.2$ & $155.0 \pm 100.6$ & $<0.001$ & $<0.001$ \\
\hline Total bilirubin (mg/dl) & $94.0 \pm 91.4$ & $102.6 \pm 89.9$ & $97.6 \pm 88.6$ & $111.1 \pm 90.1$ & $92.5 \pm 89.0$ & $90.4 \pm 88.6$ & $100.3 \pm 89.3$ & 0.402 & 0.505 \\
\hline Direct bilirubin (mg/dl) & $49.7 \pm 43.8$ & $54.6 \pm 42.6$ & $52.3 \pm 41.6$ & $58.5 \pm 42.5$ & $49.5 \pm 42.3$ & $48.6 \pm 41.9$ & $53.4 \pm 42.2$ & 0.391 & 0.408 \\
\hline AST (units/l) & $128.3 \pm 106.4$ & $123.6 \pm 99.6$ & $108.7 \pm 70.2$ & $120.8 \pm 82.1$ & $112.7 \pm 111.9$ & $98.7 \pm 67.3$ & $114.7 \pm 87.1$ & 0.316 & 0.222 \\
\hline ALT (units/l) & $76.3 \pm 60.2$ & $89.86 \pm 91.8$ & $72.2 \pm 60.7$ & $84.2 \pm 84.4$ & $76.7 \pm 100.7$ & $60.7 \pm 50.4$ & $78.9 \pm 80.0$ & 0.129 & 0.795 \\
\hline$\%$ treated with penicillin & 82.0 & 81.7 & 82.2 & 74.5 & 65.0 & 79.4 & 78.0 & 0.016 & 0.358 \\
\hline
\end{tabular}

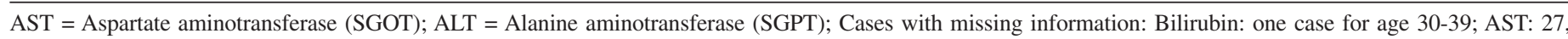

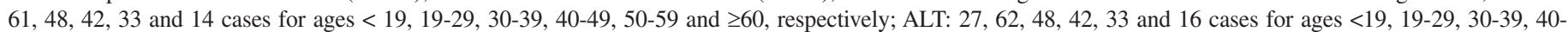
$49,50-59$ and $\geq 60$, respectively 


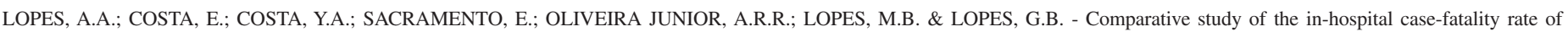
leptospirosis between pediatric and adult patients of different age groups. Rev. Inst. Med. trop. S. Paulo, 46(1):19-24, 2004.

Table 2

Dialysis, hemorrhagic events, death and duration of hospitalization by age groups

\begin{tabular}{|c|c|c|c|c|c|c|c|c|c|}
\hline & \multirow{2}{*}{$\begin{array}{l}\text { Pediatric } \\
\begin{array}{l}\leq \mathbf{1 9} \\
n=100\end{array}\end{array}$} & \multicolumn{5}{|c|}{ Adult age groups } & \multirow{2}{*}{$\begin{array}{l}\text { All Adults } \\
\begin{array}{l}\geq 19 \\
\mathrm{n}=740\end{array}\end{array}$} & \multirow[b]{2}{*}{$\begin{array}{l}\mathrm{p} \text { among } \\
\text { adults }\end{array}$} & \multirow[b]{2}{*}{$\begin{array}{l}\mathrm{p} \text { (pediatric } \\
\text { vs adults) }\end{array}$} \\
\hline & & $\begin{array}{c}19-29 \\
\mathrm{n}=213\end{array}$ & $\begin{array}{c}30-39 \\
\mathrm{n}=214\end{array}$ & $\begin{array}{c}40-49 \\
n=145\end{array}$ & $\begin{array}{c}50-59 \\
\mathrm{n}=100\end{array}$ & $\begin{array}{c}\geq 60 \\
\mathrm{n}=68\end{array}$ & & & \\
\hline$\%$ death & $\begin{array}{c}3 \\
(3 / 100)\end{array}$ & $\begin{array}{c}5.6 \\
(12 / 213)\end{array}$ & $\begin{array}{c}10.3 \\
(22 / 214)\end{array}$ & $\begin{array}{c}21.4 \\
(31 / 145)\end{array}$ & $\begin{array}{c}28.0 \\
(28 / 100)\end{array}$ & $\begin{array}{c}36.8 \\
(25 / 68)\end{array}$ & $\begin{array}{c}15.9 \\
(118 / 740)\end{array}$ & $<0.001$ & 0.001 \\
\hline$\%$ death first 2 days & $\begin{array}{c}100 \\
(3 / 3)\end{array}$ & $\begin{array}{c}66.7 \\
(8 / 12)\end{array}$ & $\begin{array}{c}50.0 \\
(11 / 22)\end{array}$ & $\begin{array}{c}58.1 \\
(18 / 31)\end{array}$ & $\begin{array}{c}60.7 \\
(17 / 28)\end{array}$ & $\begin{array}{c}60.0 \\
(15 / 25)\end{array}$ & $\begin{array}{c}58.5 \\
(69 / 118)\end{array}$ & 0.900 & 0.859 \\
\hline \multicolumn{10}{|l|}{$\%$ dialyzed } \\
\hline total group & $\begin{array}{c}14.0 \\
(14 / 100)\end{array}$ & $\begin{array}{c}15.5 \\
(33 / 213)\end{array}$ & $\begin{array}{c}28.5 \\
(61 / 214)\end{array}$ & $\begin{array}{c}33.1 \\
(48 / 145)\end{array}$ & $\begin{array}{c}30.0 \\
(30 / 100)\end{array}$ & $\begin{array}{c}44.1 \\
(30 / 68)\end{array}$ & $\begin{array}{c}27.3 \\
(202 / 740)\end{array}$ & $<0.001$ & 0.004 \\
\hline survivors & $\begin{array}{c}13.4 \\
(13 / 97)\end{array}$ & $\begin{array}{c}12.9 \\
(26 / 201)\end{array}$ & $\begin{array}{c}22.9 \\
(44 / 192)\end{array}$ & $\begin{array}{c}21.9 \\
(25 / 114)\end{array}$ & $\begin{array}{c}19.4 \\
(14 / 72)\end{array}$ & $\begin{array}{c}27.9 \\
(12 / 43)\end{array}$ & $\begin{array}{c}19.5 \\
(121 / 622)\end{array}$ & 0.053 & 0.155 \\
\hline$\%$ hemorrhagic events & $\begin{array}{c}20.0 \\
(20 / 100)\end{array}$ & $\begin{array}{c}24.4 \\
(52 / 213)\end{array}$ & $\begin{array}{c}25.2 \\
(54 / 214)\end{array}$ & $\begin{array}{c}25.5 \\
(37 / 145)\end{array}$ & $\begin{array}{c}25.0 \\
(25 / 100)\end{array}$ & $\begin{array}{c}14.7 \\
(10 / 68)\end{array}$ & $\begin{array}{c}24.1 \\
(178 / 740)\end{array}$ & 0.455 & 0.370 \\
\hline \multicolumn{10}{|l|}{$\begin{array}{l}\text { Median length of } \\
\text { hospitalization (days) }\end{array}$} \\
\hline total group & 7 & 7 & 7 & 7 & 7 & 7 & 7 & 0.274 & 0.533 \\
\hline survivors & 7 & 7 & 8 & 8 & 8 & 9 & 8 & 0.001 & 0.020 \\
\hline
\end{tabular}

the 1009 patients with information on death or survival and 14.4 for the group of 840 patients with complete information on the covariates included in the logistic regression model. As shown in Table 2, the casefatality rate of leptospirosis increased steadily with age. It varied from $3.0 \%$ for the pediatric group to $36.8 \%$ for the group $\geq 60$ years. The ages of the three fatal pediatric cases were 13, 14 and 17 years. The deaths of these three patients were attributed to renal failure. Among the 118 cases of death in adult patients, 89 were attributed to renal failure, 12 to gastrointestinal bleeding, 6 to septic shock, 4 to respiratory failure, 7 to other causes and for one patient the data on cause of death was missing. Almost $60 \%$ of the deaths occurred 48 hours after admission. The percentage of these early deaths did not differ significantly by age ( $\mathrm{p}=$ $0.755)$. Similarly, significant variation in early death was not observed ( $\mathrm{p}=0.427$ ) between patients with duration of symptoms $\leq 4$ days (16 out of $30,53.3 \%$ ) and $>4$ days (56 out of $91,61.5 \%$ ) The percentage of patients who received dialysis varied significantly by age, being higher for older groups $(\mathrm{p}<0.001)$. This difference in dialysis treatment by age remained significant $(\mathrm{p}=0.04)$ in the analysis restricted to patients who have not died during hospitalization. The percentages of patients with hemorrhagic events were $20.0 \%$ in the pediatric group and $24.1 \%$ in the adult group $(p=0.370)$. In the pediatric group the frequency of hemorrhagic events was 4.6 times higher for ages 15-18 than for ages $\leq 14$ years $(\mathrm{p}=0.011)$. The median length of hospitalization was seven days for each of the six age groups. On the other hand, among survivors median length of hospitalization was significantly associated with age ( $p=0.001$ ), being longer (median difference $=2$ days) in patients $\geq 60$ years than in patients $\leq 30$ years.

Table 3 shows the odds ratios of the association between baseline patient characteristics and in-hospital death, estimated by logistic regression models. Age, creatinine and urea were significantly and independently associated with death. The odds of death adjusted for gender, jaundice, serum creatinine, serum urea and duration of symptoms, increased $66 \%$ for each 10-year increase in age (adjusted $\mathrm{OR}=1.66$;

Table 3

Odds ratios of the association between baseline patient characteristic and in-hospital death

\begin{tabular}{|c|c|c|c|c|}
\hline & \multicolumn{2}{|c|}{ Unadjusted model } & \multicolumn{2}{|c|}{ Adjusted Model } \\
\hline & Odds ratio $(95 \% \mathrm{CI})$ & $\mathrm{p}$ value & Odds ratio $(95 \% \mathrm{CI})$ & $\mathrm{p}$ value \\
\hline Age per 10 years & $1.72(1.51-1.97)$ & $<0.001$ & $1.66(1.42-1.94)$ & $<0.001$ \\
\hline Adult group (vs pediatric group) & $6.13(1.91-19.68)$ & 0.001 & $3.94(1.19-13.03)$ & 0.029 \\
\hline Male (vs female) & $0.75(0.47-1.19)$ & 0.467 & $1.17(0.70-2.03)$ & 0.563 \\
\hline Jaundiced (vs no) & $4.09(1.27-13.20)$ & 0.011 & $2.56(0.70-9.44)$ & 0.157 \\
\hline Creatinine per $1 \mathrm{mg} / \mathrm{dl}$ & $1.37(1.27-1.48)$ & $<0.001$ & $1.33(1.23-1.45)^{*}$ & $<0.001$ \\
\hline Urea per $30 \mathrm{mg} / \mathrm{dl}$ & $1.29(1.22-1.37)$ & $<0.001$ & $1.24(1.17-1.32)^{*}$ & $<0.001$ \\
\hline$>4$ days of symptoms (vs $\leq 4$ days) & $0.96(0.62-1.51)$ & 0.888 & $0.65(0.40-1.09)$ & 0.106 \\
\hline
\end{tabular}

* Because of multicollinearity urea and creatinine were not included together in the logistic model used to estimate the adjusted odds ratio for each of these two variables. For the other adjusted odds ratios (i.e., for age, gender, jaundice, and duration of symptoms) both urea and creatinine were included in the logistic model. 


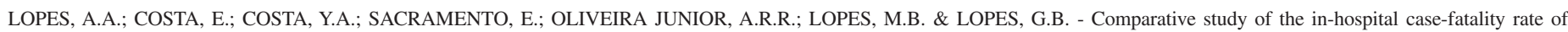
leptospirosis between pediatric and adult patients of different age groups. Rev. Inst. Med. trop. S. Paulo, 46(1):19-24, 2004.

$\mathrm{p}<0.001)$. Jaundice was associated with death only in the unadjusted analysis. Gender and duration of symptoms were not significantly associated with death. The adjusted odds of death were almost four times higher for adult than for pediatric patients $(\mathrm{OR}=3.94, \mathrm{p}=0.029)$.

Figure 1 shows a more detailed picture of the adjusted association between age and the odds of death by logistic regression. The odds of death increased significantly with age ( $\mathrm{p}$ for trend $<0.001$ ). Compared with the pediatric group, the adjusted odds of death were significantly higher for all age groups $\geq 40$. Among adults significant adjusted differences in the odds of death were also observed between the age group 19-29 and the age groups $\geq 40$. Similar logistic regression adjusted odds ratios were observed by using models restricted to icteric patients.

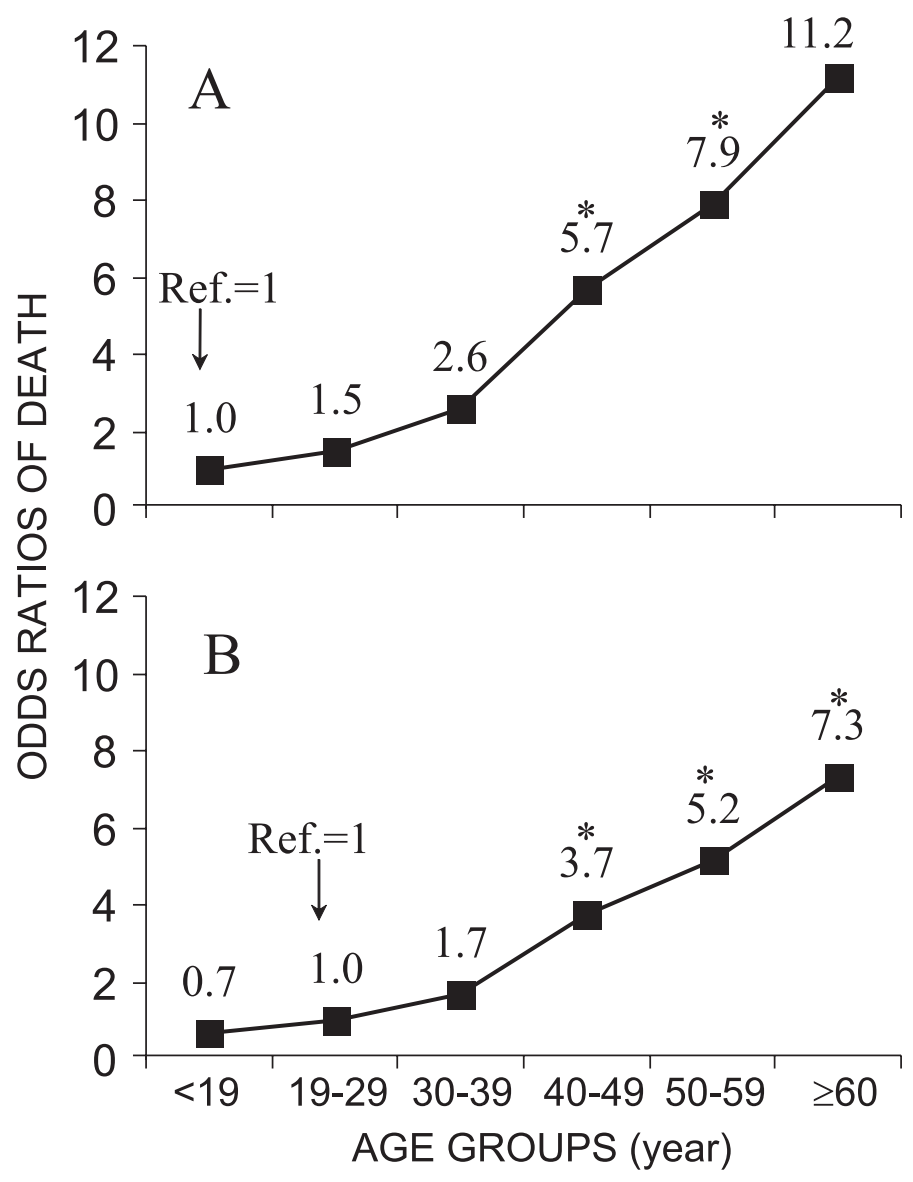

Fig. 1 - Logistic regression adjusted odds ratio of death by age group, using the pediatric group (A) and the the age group 19-29 (B) as referent. The adjusted model included gender, jaundice, creatinine (as continuous variable), urea (as continuous variable) and duration of symptoms ( $>4$ days vs $\leq 4$ days). The odds ratio after the addition of penicillin in the model with the pediatric group as referent were: $1.5(\mathrm{p}>0.05), 2.6(\mathrm{p}>0.05), 5.8(\mathrm{p}<0.01), 8.0(\mathrm{p}<$ $0.01)$ and 11.2(p $<0.01$ ), for ages $<19-29,30-39,40-49,50-59$ and $\geq 60$, respectively $* \mathrm{p}<$ 0.01 . Odds ratios in a logistic model restricted to icteric patients, adjusted for creatinine, urea and duration of symptoms, using the age group $<19$ as referent were: 1.5 ( $p>0.05), 2.5$ ( $p>$ $0.05), 5.4(\mathrm{p}<0.01), 7.4(\mathrm{p}<0.01)$ and $11.3(\mathrm{p}<0.01)$, for ages 19-29, 30-39, 40-49, 50-59 and $\geq 60$, respectively.

\section{DISCUSSION}

The case-fatality rate of leptospirosis was significantly lower for the pediatric group than for the adult group. Moreover, among adults the case-fatality rate of leptospirosis increased steadily from the younger to the older groups. According to our data, among patients hospitalized with leptospirosis approximately one out of 10 with ages 19 to 49 and one out of four with ages above 49 years died from the disease. In addition to a higher mortality risk, older patients were also more often treated by dialysis both among those who survived and among those who died. Among survivors, older patients had a longer median length of hospitalization.

As consistently reported in studies among patients hospitalized with leptospirosis there was a predominance of males. Despite the higher mean age of females, a higher, but non-statistically significant, mortality risk was observed for males. The direction of this association between gender and risk of death, however, was inverted and remained statistically non-significant after the logistic regression adjustment for the higher average age of women. A similar observation was described by $\mathrm{KO}$ et $a l$. in a study also developed at Couto Maia Hospital ${ }^{10}$.

Higher prevalence of jaundice at hospital admission, and higher levels of serum creatinine and urea were observed in older than in younger patients. Because the distribution of serum creatinine in the general population and in patients with renal diseases varies by age we used different cut points for the serum creatinine. Both in the pediatric and the adult groups, more than $90 \%$ of the patients had serum creatinine $>$ $1.2 \mathrm{mg} / \mathrm{dl}$ at hospital admission. The differences by age were statistically significant only for serum creatinine $>3.0 \mathrm{mg} / \mathrm{dl}$. In a study developed in São Paulo, Brazil, MAROTO et al. reported a frequency of $79 \%$ cases of renal failure, defined as serum creatinine $>1.0 \mathrm{mg} / \mathrm{dl}$, in 43 children with leptospirosis, 4-14 years of age ${ }^{12}$. In our study a higher frequency $(94.1 \%)$ of patients with serum creatine $>1.0 \mathrm{mg} / \mathrm{dl}$ was observed among 34 children with ages $\leq 14$ years. The frequency of serum creatinine $>1.0 \mathrm{mg} / \mathrm{dl}$ was similar between ages $\leq 14$ and $15-18$ years. As observed for age, levels of urea and creatinine and the presence of jaundice were also significantly associated with higher risk of death. However, according to our results, jaundice and degree of renal failure cannot fully explain the strong association between age and case-fatality rate of leptospirosis.

In the present study the use of penicillin was not associated with mortality risk and did not influence the association between age and the odds of death in patients with leptospirosis. However, since our study was retrospective, the results do not permit the conclusion that penicillin is not beneficial for the patients that are hospitalized with leptospirosis. Two previous retrospective studies have suggested that antimicrobial therapy is beneficial for both children and adult with leptospirosis, by reducing the extent of renal failure, thrombocytopenia or by shortening the duration of illness ${ }^{9,12}$. Similar to our study, the results of those studies do not permit to conclude that antimicrobial therapy reduce the risk of death in patients hospitalized with leptospirosis. WATT et al., in a randomized, double-blinded clinical trial among patients with predominantly advanced leptospirosis, showed a smaller duration of hospital stay and fever in patients treated with penicillin ${ }^{22}$. In this study by WATT et al., however, it was not possible to assess the effect of penicillin on the case-fatality rate because there was no death case, both in the penicillin and the placebo groups. Results of our randomized 


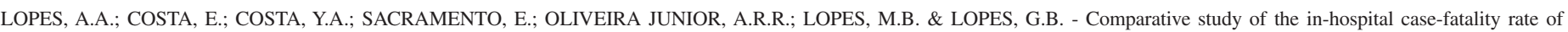
leptospirosis between pediatric and adult patients of different age groups. Rev. Inst. Med. trop. S. Paulo, 46(1):19-24, 2004.

clinical trial in 253 leptospirosis patients 15 years of age or older, also admitted to Couto Maia Hospital, suggest that the initiation of penicillin after the fourth day of symptomatic disease is not associated with a reduced risk of death. It has been shown, however, that the use of antibiotics after high-risk exposure reduces the incidence of severe leptospirosis ${ }^{8,16,20}$.

Because there were outbreaks of dengue during the period that the patients were admitted to the hospital there was a concern that some patients believed to have leptospirosis had in fact dengue and viceversa $^{5,21}$. It should be noted, however, that diagnostic confusion with dengue is likely to occur among patients with symptoms consistent with less severe forms of leptospirosis, i.e., patients who are anicteric and do not have renal failure. The majority of our patients were icteric or had renal failure, findings that are consistent with the fact that the serogroup icterohaemorrhagiae is the most frequently identified in patients admitted to Couto Maia Hospital, where this study was developed ${ }^{1,10}$. Thus, during the outbreaks of dengue fever the diagnosis of leptospirosis could be delayed but misclassification of leptospirosis with dengue should be seen as very unlikely in this sample, particularly among the icteric patients. The fact that the age comparisons of mortality risk did not change after restricting the analysis to icteric patients is an additional piece of evidence that diagnostic misclassification should not have biased our results toward a higher risk of death among adults as compared to the pediatric patients. Missing data on death for patients transferred to other hospitals should also not have biased the results, since whatever were the outcome (i.e., death or survival), the trend to increase the casefatality rate with age would be present.

In conclusion, our data show evidence that pediatric patients have a lower risk of death during hospitalization than adult patients with leptospirosis. In addition, among adults, the mortality risk increased steadily with age. Older patients were also more often treated by dialysis and, among survivors, had longer length of hospitalization. Research is still needed to identify the determinants of the high risk of death in adults (as compared with pediatric patients) and older patients with leptospirosis. We need also to identify which treatment interventions may improve the prognosis of leptospirosis and reduce the gap in the mortality risk between older and younger patients. The improvement in the sanitary conditions of the urban cities in Brazil and the implementation of other preventive measures should reduce the incidence of leptospirosis and decrease the morbidity and mortality related to this disease.

\section{RESUMO}

\section{Estudo comparativo da letalidade hospitalar da leptospirose entre pacientes pediátricos e adultos de diferentes grupos etários}

O objetivo principal foi comparar a letalidade hospitalar da leptospirose entre pacientes pediátricos ( $<19$ anos) e adultos ( $\geq 19$ anos), levando em consideração gênero, função renal, duração dos sintomas e icterícia. Prontuários de 1016 pacientes foram revistos. Análise comparativa foi restrita a 840 pacientes (100 pediátricos, 740 adultos) com informações sobre as variáveis incluídas na análise. Entre estes pacientes $81,4 \%$ eram do sexo masculino e $91,5 \%$ apresentavam icterícia à admissão. A letalidade da leptospirose foi 14,4\%. A razão entre número de pacientes que morreram e número de pacientes que sobreviveram, ajustada para gênero, icterícia, duração de sintomas, uréia sérica e creatinina sérica foi quase quatro vezes maior no grupo adulto do que no pediátrico (odds ratio $(\mathrm{OR})=3,94$; intervalo de confiança de $95 \%=$ 1,19-13,03, $\mathrm{p}=0,029)$. Em adultos, idade mais avançada foi também significantemente e independentemente associada com maior risco de morte $(\mathrm{p}<0,01)$. Pacientes mais velhos foram também mais freqüentemente dialisados. Em conclusão, os dados mostram que a letalidade da leptospirose é mais alta em adultos do que em crianças e adolescentes, mesmo após o ajuste para os efeitos de potenciais fatores de risco de morte. Entre adultos, idade avançada mostrou-se também associada fortemente e independentemente com risco mais alto de morte.

\section{ACKNOWLEDGMENTS}

The work was partially supported by the "Conselho Nacional de Ciência e Tecnologia, CNPq”, grant 520823 / 97-4.

\section{REFERENCES}

1. CALDAS, E.M.; COSTA, E. \& SAMPAIO, M.B. - Leptospirose na cidade do Salvador (Brasil). Alguns aspectos clínicos e laboratoriais. Rev. Inst. Med. trop. S. Paulo, 20: 164-176, 1978.

2. COSTA, E.; COSTA, Y.A.; LOPES, A.A.; SACRAMENTO, E. \& BINA, J.C. - Formas graves de leptospirose: aspectos clínicos, demográficos e ambientais. Rev. Soc. bras. Med. trop., 34: 261-267, 2001.

3. CRUZ, M.L.; ANDRADE, J. \& PEREIRA, M.M. - Leptospirose em crianças no Rio de Janeiro. Rev. Soc. bras. Med. trop., 27: 5-9, 1994.

4. DE FIGUEIREDO, C.M.; MOURAO, A.C.; DE OLIVEIRA, M.A. et al. - Leptospirose humana no município de Belo Horizonte, Minas Gerais, Brasil: uma abordagem geográfica. Rev. Soc. bras. Med. trop., 34: 331-338, 2001.

5. DIAS, J.; PEDRAL-SAMPAIO, D.B. \& JONES, T.C. - Aedes aegypti surveillance and correlation with the occurrence of dengue fever in Bahia, Brazil. Braz. J. infect. Dis., 1: 36-41, 1997.

6. FAINE, S. - Guidelines for the control of leptospirosis. Geneva, World Health Organization, 1982. p. 1-171. (WHO publication No. 67).

7. FLANNERY, B.; PEREIRA, M.M.; VELLOSO, L.F. et al. - Referral pattern of leptospirosis cases during a large urban epidemic of dengue. Amer. J. trop. Med. Hyg., 65: 657-663, 2001.

8. GONSALEZ, C.R.; CASSEB, J.; MONTEIRO, F.G. et al. - Use of doxycycline for leptospirosis after high-risk exposure in São Paulo, Brazil. Rev. Inst. Med. trop. S. Paulo, 40: 59-61, 1998.

9. KATZ, A.R.; ANSDELL, V.E.; EFFLER, P.V.; MIDDLETON, C.R. \& SASAKI, D.M. Assessment of the clinical presentation and treatment of 353 cases of laboratoryconfirmed leptospirosis in Hawaii, 1974-1998. Clin. infect. Dis., 33: 1834-1841, 2001.

10. KO, A.I.; GALVÃO REIS, M.; RIBEIRO DOURADO, C.M.; JOHNSON Jr., W.D. \& RILEY, L.W. - Urban epidemic of severe leptospirosis in Brazil. Salvador Leptospirosis Study Group. Lancet, 354: 820-825, 1999.

11. KUPEK, E.; FAVERSANI, M.C.S.S. \& PHILIPPI, J.M.S. - The relationship between rainfall and human leptospirosis in Florianopolis, Brazil, 1991-1996. Braz. J. infect. Dis., 4: 131-134, 2000.

12. MAROTTO, P.C.; MAROTTO, M.S.; SANTOS, D.L.; SOUZA, T.N. \& SEGURO, A.C. - Outcome of leptospirosis in children. Amer. J. trop. Med. Hyg., 56: 307-310, 1997. 
LOPES, A.A.; COSTA, E.; COSTA, Y.A.; SACRAMENTO, E.; OLIVEIRA JUNIOR, A.R.R.; LOPES, M.B. \& LOPES, G.B. - Comparative study of the in-hospital case-fatality rate of leptospirosis between pediatric and adult patients of different age groups. Rev. Inst. Med. trop. S. Paulo, 46(1):19-24, 2004.

13. NORUSIS, M.J. - SPSS for Windows: base system user's guide, release 6.0. Chicago, SPPS, 1993.

14. PEREIRA, M.M. \& ANDRADE, J. - Human leptospirosis in a slum area in the city of Rio de Janeiro, Brazil: a serological and epidemiological study. Mem. Inst. Oswaldo Cruz, 85: 47-52, 1990.

15. SARKAR, U.; NASCIMENTO, S.F.; BARBOSA, R. et al. - Population-based casecontrol investigation of risk factors for leptospirosis during an urban epidemic. Amer. J. trop. Med. Hyg., 66: 605-610, 2002.

16. SEHGAL, S.C.; SUGUNAN, A.P.; MURHEKAR, M.V.; SHARMA, S. \& VIJAYACHARI, P. - Randomized controlled trial of doxycycline prophylaxis against leptospirosis in an endemic area. Int. J. Antimicrob. Agents, 13: 249-255, 2000.

17. SILVA, H.R.; TAVARES-NETO, J.; BINA, J.C. \& MEYER, R. - Leptospirose-infecção e forma subclínica em crianças de Salvador, Bahia. Rev. Soc. bras. Med. trop., 36: 227-233, 2003

18. SUÁREZ HERNÁNDEZ, M.; MARTÍNEZ SÁNCHEZ, R.; POSADA FERNÁNDEZ, P. et al. - Leptospirosis en niños de la Provincia de Ciego de Ávila, Cuba. Rev. Soc. bras. Med. trop., 32: 145-150, 1999
19. SUPERINTENDÊNCIA DE VIGILÂNCIA E PROTEÇÃO À SAÚDE. DIRETORIA DE VIGILÂNCIA EPIDEMIOLÓGICA - Avaliação epidemiológica da leptospirose no Estado da Bahia. Salvador, Secretaria da Saúde do Estado da Bahia, 1999.

20. TAKAFUJI, E.T.; KIRKPATRICK, J.W.; MILLER, R.N. et al. - An efficacy trial of doxycycline chemoprophylaxis against leptospirosis. New Engl. J. Med., 310: $497-$ $500,1984$.

21. TEIXEIRA, M.G.; COSTA, M.C.; BARRETO, M.L. \& BARRETO, F.R. - Epidemiologia do dengue em Salvador-Bahia, 1995-1999. Rev. Soc. bras. Med. trop., 34: 269274,2001

22. WATT, G.; PADRE, L.P.; TUAZON, M.L. et al. - Placebo-controlled trial of intravenous penicillin for severe and late leptospirosis. Lancet, 1: 433-435, 1988.

Received: 15 July 2003

Accepted: 6 January 2004 